\title{
Emerging Mall Culture and Shopping Behavior of Young Consumers
}

\author{
Ramandeep Bawa1 ${ }^{*}$, Anil Kishore Sinha1, Rita Kant ${ }^{2}$ \\ ${ }^{1}$ Department of Anthropology, Panjab University, Chandigarh, India \\ ${ }^{2}$ Department of Fashion Technology, Panjab University, Chandigarh, India \\ Email:^sodhiramandeep9@gmail.com, ^doc.ritak@gmail.com
}

How to cite this paper: Bawa, R., Sinha, A. K., \& Kant, R. (2019). Emerging Mall Culture and Shopping Behavior of Young Consumers. Advances in Anthropology, 9, 125-150.

https://doi.org/10.4236/aa.2019.93010

Received: May 12, 2019

Accepted: June 16, 2019

Published: June 19, 2019

Copyright $\odot 2019$ by author(s) and Scientific Research Publishing Inc. This work is licensed under the Creative Commons Attribution International License (CC BY 4.0).

http://creativecommons.org/licenses/by/4.0/

\begin{abstract}
Malls are attracting the young shoppers and mall culture is new to the society. Mall retailers are making efforts to satisfy the young consumers. However, the younger segment is growing in terms of population and wealth. It has become increasingly important and necessary to understand and meet their demands. The study employed 160 in-depth interviews to understand the young consumers' mall experiences. Overall, the respondents in the study have favourable perception of the mall in terms of convenience, variety offered by malls, awareness of brands, aesthetics and hedonic factors. The researcher found eight elements that are important for young consumers to form impression of the shopping malls: convenience, choice, awareness, crowded/congested, ambience, parking, hedonic shopping and mall culture. Further the respondent studied the total number of hours on shopping, preference of shopping day and shopping time by young consumers. It was found that maximum number that respondents spend is up to $3 \mathrm{hrs}$ on shopping, however weekends were preferred in comparison to weekdays. Maximum respondents preferred shopping at any suitable timing. The researcher also investigated specific mall attributes. Respondents also suggested that various attributes are considered important by the respondents. They highlighted various attributes-sitting arrangement, water dispensers, E-mapping, plain ramps, book browsing section and further expressed their concern regarding parking, security and customer service. The results can help mall retailers in capitalizing the consumers by meeting their needs.
\end{abstract}

\section{Keywords}

Shopping Malls, Mall Culture, Ambience, Parking, Sitting Arrangement, Mall Attributes 


\section{Introduction}

Business and Industry are the most constructive ways of organising economic activities to meet basic human needs in global markets today. The term "business anthropology" came into usage in the 1980s when anthropologists were hired as full time practitioners in fields merely related to consumer behaviour and marketing. Anthropology as a field has been widely used in the business world. Underhill (2009) suggested that Anthropology has devoted a branch to study the science of shopping, retail anthropology and anthropological study of shopping malls. Today shopping in malls is not just buying products or acquiring goods for our households. It is also interacting with retail environments (stores, banks, restaurants) investigating economic and social functions of malls, shopping experience and their meaning to shoppers. Anthropologist, Underhill has been applying his anthropological skills to study the perspective of shopping for last 50 years. It can be said that more specifically, anthropology addresses answers to many questions: What is the reason for people shopping, Who does most of the shopping, What enhances the experience of shopping and What do shoppers gain from their shopping experience, How does shopping affect the relationship between family members and friends?

As the standard of living has increased, the purchasing power of consumers has increased manifolds. According to India consumer spending (2004-2017) Consumer Spending in India has increased from 17,809.14 billion INR (fourth quarter of 2016) to 18,483 INR Billion in the first quarter of 2017; however, the average spending in 2004 was very low i.e. 9987.55 INR Billion which has reached a height of 18,483 INR Billion in 2017. According to Knight Frank report (2015), the total retail spending in the top seven cities of India amounts to Rs. 3586 bn (US \$ 59.8 bn) with Mumbai at the top (29\%) followed by NCR (25\%), Bengaluru (15\%), Kolkata (8.9\%), Hyderabad (8.8\%), Pune (6.6\%) and Chennai (6.2\%).

(https://content.knightfrank.com/research/317/documents/en/india-retail-repor t-2646.pdf).

According to the Bureau of Labour Statistics US (2013) consumers under age 25 have the highest share of overall spending on food away from home i.e. 6.9 percent. This age group also had the highest shares of total spending on education (6.8\%), apparel and services (5.0\%), entertainment (4.1\%), alcoholic beverages (1.2 percent). The consumers aged 25 to 34 had the highest share of spending on housing (35.8\%) and transportation (19.1\%). However their spending on food away from home (5.5\%) and entertainment (4.6\%) was ranked third and fifth among all age groups. Moreover their spending on education was just $2.1 \%$.

Shopping habits of Indians are changing due to increase in the younger population, their growing disposable income and the change in attitudes towards shopping. The desire to look and feel good is an important factor influencing customers towards their purchase decisions. Age is also a major factor that affects the spending decisions of an individual. For instance, people in $20-24$ 
years age group tend to spend more on electronic/home appliances and movies, while people in the 45 - 48 years age group spend more on vacations.

(http://www.icmrindia.org/casestudies/catalogue/Business\%20Reports/BREP047 .htm). So to fulfill the shopping needs of consumers, shopping centres in Chandigarh (India) are continually proliferating and increasing in size. However, in order to leave strong impression on shoppers. Malls nowadays employ various strategies to attract customers and enhance their shopping behaviour. Malls play an important role in consumers' lifestyle (Bloch, Ridgway, \& Dawson, 1994). The attractiveness of malls depends upon as they fulfill consumers' personal and social needs (Tauber, 1972; Hernandez \& Jones, 2005).

\subsection{Shopping and Shopping Behaviour}

Assael (1987), defined shopping as a most unique form of behavior which the consumers exhibit. Groceries, gifts, apparel and household items are some of the common type of items which consumers indulge in frequently. Underhill (2009) asserted shopping is very distinctive in nature, it is not just purchasing but it actually involves the customer's acceptance of brands, products and stores as well by the use of multiple senses like-seeing, hearing and even tasting at times. South \& Spitze (1994), and Fram \& Axelrod (1990), opined that shopping is a women's activity and they are the ones' responsible for household shopping. Oakley (1975) considered shopping to have the most positive attribute of being a leisure activity. Howard (2007) also believed shopping to be a leisure pursuit and with the development of shopping centers, developers and retailers are trying to make it a pleasure activity. Howard (2007) revealed that a lot of studies on consumer behaviour have been investigated and they have found insights into the situational and personal experiences of shopping and its effect on human behaviour and emotions. Many studies have explored the motives behind shopping. Babin et al. (1994) examined that the purpose of shopping can be utilitarian and non utilitarian or hedonic. Shopping behaviour of consumers is different in different countries. The reasons for varying shopping behaviour are brought by diversity of culture and the changing economies of the various countries (Millan \& Howard, 2007).

Dholakia (1999) Frequency of shopping is also considered to be an important and significant concept while studying shopping behavior of Consumers. It is defined as the number of times a product is purchased by someone in person or physically. Frequency of shopping is also subject to the time and effort put by a person, Moreover Shopping is also related to gender and his/her responsibility for the household. It is also determined by the context of shopping. Dholakia (1999) opined shopping means making physical visits to stores or shopping sites. The author further mentioned that occasion and motives also influence shopping behavior of consumers. Shopping is also considered as a household task as well as a form of entertainment and relaxation. Dholakia (1999) has provided a framework for understanding the shopping behavior of consumers. 


\subsection{Shopping Malls}

The shopping mall was originally conceived as community centres where people would converge for shopping, social interaction and cultural activities (Gruen \& Smith, 1960). During the 1980s, mall was a popular destination for shopping and recreation (Kowinski, 1985).

Feinberg \& Meoli (1991) discussed that half of the retail sales were mall transactions in the early 1990s. Malls have succeeded in achieving the old age purpose of bringing malls into existence. Hence in today's consumer culture' "Mall" is the centre of the universe (Feinberg \& Meoli, 1991). Even if people have less time, but they will take time for activities they enjoy (Ashley, 1997). According to Nicholls et al. (2002), shopping malls is a place where large number of retail outlets (tenant-mix) are positioned under one roof and is usually anchored by one or more stores. Carlson (1991) has examined that traditionally, shopping centres had more departmental stores but now the presence of speciality stores, branded apparels and cinema halls are considered equally important. People consider the retail environment to have an influence on the emotional behaviour of consumers and thus influences shopping behaviour (Donovan \& Rossiter, 1982). Malls have redefined the consumer' definition of shopping and served as catalysts to new culture (Stockil, 1972).

\subsection{Importance of Mall Attributes and Shopping Behaviour}

El-Adly (2007) identified six mall attractiveness factors namely comfort, entertainment, diversity, mall essence, convenience and luxury. The shoppers in this study spend less than two hours on their shopping and prefer weekends. Shoppers regarded great importance to attributes like security, cleanliness, sitting arrangement, parking, variety, quality of products and after sales service. Venkateswarulu \& Uniyal (2007) found that attractiveness of a mall depend upon Convenience, amenities, ambience, personnel, parking and seating. They also suggested some attributes like restrooms, smell, parking, security as important factors attracting shoppers towards malls. Nicholls et al. (2002) also mentioned that Scarcity of time, choice of retail outlet, store attributes, variety of merchandise available and even scents/fragrance in a retail environment affect buying behaviour. White \& Sutton (2001) discussed mall space and its characteristics. Physical characteristics of shopping malls include the provision for sense of safety and security that people need. Social environment of the mall spaces includes attributes such as the total number of sales staff, helpfulness of salespeople, managers, other employees in the mall environment.

According to Loudon \& Bitta (1993), consumers seek high convenience while visiting malls. They spend time and effort for finding parking space, department or particular product. They also found that convenience is an important criterion for customers who are visiting malls infrequently. Now consumers can shop without worrying about parking problems and security issues (Ooi \& Sim, 2007; Nicholls et al., 2002). According to Kaufman (1996), consumers are getting more 
attracted towards "one stop destination" for satisfying their shopping desires, thus complementing the emergence of mall culture.

Stores, restaurants, food courts, restaurants, kid play zones, places for relaxation, areas for social use, interaction, entertainment and promotions are major components for any mall (Terblanche, 1999). The mall is a separate complex of shops, department stores, groceries, services, and entertainment which simultaneously meet all kinds of needs and offer something new (Falk \& Campbell, 1997). The shopping centre provides all facilities to the consumers ranging from having bookstores, beauty salons, food courts, medical aid and grocery stores. Malls also facilitate shoppers with numerous variety of branded clothes and shoes, beauty and fashion products, furniture and home furnishings and amusement centres for kids. Malls add a term "fun" aspect to shopping (Berry et al., 2002).

A study by (Tauber, 1972; Bloch et al., 1994) mentioned that one visits malls in order to relieve stress, alleviate the negative mood and forget about their problems. Tauber (1972) further mentioned that Malls attracts shoppers by offering an opportunity to learn new trends. Wakefield \& Baker (1998) asserted that Socialisation is an important factor relating to shopping experience. Loudon \& Bitta (1993) examined that most of the people prefer to shop at locations where employee's behaviour was kind and courteous. Oppewal (1995) mentioned that the choice to choose a shopping destination is influenced by various attributes/determinants such as "price and quality of products", array of products, "distance from home to shopping destination" and "parking situation". Oppewal (1995) "parking situation" is also defined as having a shopping area surrounded with land for parking convenience available at a parking cost. Other attributes of the parking situation are "parking search time" (Timmermans et al., 1984), "number of parking spaces" (Timmermans et al., 1992), "quality of parking facilities" (Timmermans \& Waerden, 1992) and "availability of parking facilities" (Timmermans, 1996).

Academic research has revealed that many consumers make decision regarding where to shop on the basis of their attitude towards variety of stores and shopping centre environment (Finn \& Louviere, 1990; Gentry \& Burns, 1977). Customers take time and often reach destination malls that offer best variety of stores and merchandise (Ashley, 1997). Ontario Mills (A California mall) and West Edmonton Mall (world largest mall) offer an exciting shopping environment, as they provide large variety of stores (214 stores and 800 stores, respectively) (Bird, 1997; Carlisle, 1997). Wakefield \& Baker (1998) discussed that variety of stores in a mall generates positive emotions and excitement. The impression of the mall is based upon entertainment facilities, a combination of functional and psychological factors (Hook, 1989; Babin, Darden, \& Giffith, 1994; Holbrook, 1999; Arnold \& Reynolds, 2003).

Howard (1993) mentioned that consumers' also look for convenient access, good tenant mix i.e. Variety of stores, parking facilities and shopping centre size 
while preferring a mall. The challenge lies in creating a mall environment that influences consumers' shopping behaviour (Babin \& Attaway, 2000; Stoel, Wickliffe, \& Lee, 2004; Laroche et al., 2005). Wakefield \& Baker (1998) discussed that consumers accumulate information by exploring various products or stores. Consumers always look for new and upgraded products, so it is important for malls to offer a variety of products for an improved mall performance (Kaufman, 1996). Berman \& Evans (1995) discussed tenant mix, malls that offer store balance and tenant variety are likely to attract more shoppers it generates excitement, as one-stop shop allows shoppers to compare product offerings. The ambience factors in the malls comprised of interiors, colours, lightning, temperature, music, crowd and cleanliness (Donovan \& Rossiter, 1982; Donovan et al., 1994) and this in turn affects consumer's moods and emotions and influences their purchase behaviour. Loudon \& Bitta (1993) opined that a better Interior design would actually helps to enhance the image of the mall. Lui (1997) complemented his findings and revealed that Malls have seen a radical change in the interiors; consumers prefer a mall which provides a relaxed environment along architecturally lavish and sophisticated environment.

Wakefield \& Baker (1998) found mall's interior design had strong influence on customers desire to stay longer in the mall. Wakefield \& Baker (1998) also found a positive and strong relationship between the mall's layout and desire to stay in the mall. They mentioned that customers not only evaluate the product assortments inside the mall but they also considered colors, ambience, fragrance, lighting and music as important factors that enhances buyer's mood and enhances mall image. Wilhelm \& Mottner (2005) mentioned that teenagers preferred going to a shopping mall whose atmosphere was friendly. They preferred a mall which provided cool stores, entertainment options, attractive designing and a good place to spend time with friends and an overall shopping experience.

\section{Objectives}

This paper examines the perception of young consumers in the age group (23 34) towards shopping malls. The relative influence of the study was to understand preference towards various attributes i.e. convenience, variety of stores, brand awareness, hedonic shopping, aesthetics, mall culture that forms an impression of the mall. Moreover, the study was undertaken with an objective to study the preference for shopping time, shopping day, number of hours, preference of brands and stores. Finally we examined the determinants of malls that were considered important and required by the consumers like sitting arrangement, Basic necessities (caretaker, Gym, shuttle service, emergency medical aid), escalators, Security, E-mapping, Atmosphere, Customer service, Book browsing and requirement for more brands. The study contributes to literature in many ways. First it attempts to study the shopping Malls (Nicholls et al., 2002; Feinberg \& Meoli, 1991) and the nature of influence of Convenience, sitting arrangement, parking, security (El-Adly, 2007; Venkateswarulu \& Uniyal, 2007), 
parking (Oppewal, 1995; Timmermans et al., 1984; Timmermans et al., 1992; Timmermans \& Waerden, 1992; Timmermans, 1996). Variety of stores (Finn \& Louviere, 1990; Gentry \& Burns, 1977; Ashley, 1997; Wilhelm \& Mottner, 2005), ambience (Loudon \& Britta, 1993; Donovan \& Rossiter, 1982), Socialisation (Tauber, 1972; Wakefield \& Baker, 1998) and after sales service (White \& Sutton, 2001) on customer shopping experience.

Secondly, a number of studies have examined the preferences of shopping day, shopping time, number of hours (Lekshmi \& Jawahar, 2012; El-Adly, 2007) and amount spend by consumer's while visiting shopping malls. The study also elaborated on effect of crowd (Eroglu \& Machleit, 1990; Hui \& Bateson, 1991; Machleit \& Eroglu, 2000) that has negative influence on atmospheric perceptions.

Thirdly, the impact of mall culture was studied on the lifestyle of consumers. The present research will contribute to a better understanding of Mall Culture (i.e. the role of malls in daily lives) and how the Mall Culture influences the thinking process of consumers.

\section{Research Methodology}

A broad perspective to understand the motivations and needs of young consumers requires an exploratory qualitative research along with quantitative aspects. This would capture young consumer's perception and attitude regarding shopping mall experiences. To analyse this, 160 respondents were interviewed from the faculty of arts and sciences. On an average, 10 respondents each from Science and Arts faculty were selected for data collection, 83 respondents were interviewed from science faculty depending upon the availability of the respondents while 77 respondents were interviewed from Art faculty. For the present research work purposive sampling, Interview schedule and convenient sampling methods were used to carry out the research work. Qualitative technique allowed respondents to describe their experiences without imposing predetermined options and provided a richer and more accurate set of responses. Whereas the quantitative options help to interpret answers more easily and accurately.

\subsection{Design of Interview Schedule and Pretesting}

We framed a list of questions based on our review of literature on shopping malls and studies conducted on young shoppers. A detailed interview schedule was framed and respondents were asked to describe what comes to their mind when they think of malls. They were then asked to elaborate on their choices. The schedule captured the view point of respondents regarding the impression and image they have about shopping malls.

A second section consisted of quantitative research, questions related to their shopping behaviour were asked with multiple choices given to know their concerns and issues regarding shopping in malls.

How often do you visit a shopping mall?

How many hours do you usually spend in shopping? 
Shopping day preference and shopping time preference?

What is the amount in rupees you usually spend in a mall on each visit?

Third section consisted of interviews, where the respondents were interviewed regarding additional facility they would like a mall to have. Sitting corners and water dispensers were the major issues concerning them. Further the researcher during the interview, asked questions about their opinion on parking, lightning and security and convenience of reaching the mall. Shopping behavior of research scholars was analyzed with regard to age, religion, marital status, income, caste, family type, and place of birth and Hostler/Day scholar. These variables were researched to study the preference of research scholars towards shopping at malls.

Pilot interviews were conducted with 50 students which helped to identify repetitive and ambiguous question. Questions that were missing in the initial list were included in the final interview schedule.

\subsection{Data Analysis Methods}

A quantitative and qualitative approach was employed. A grounded approach using an open coding technique was employed, where the researcher coded the open-ended question and the themes were identified for each question. Further the interviews were sorted into categories. Generally, In-depth Interviews are conducted in this method. Interview schedule, observation, and narratives were employed for collection of data. Thus the present study has used mixed method approach for data collection. Some of the interviews were quantified such as (preference of shopping day, shopping time, number of hours spend on shopping, Average Amount spent on shopping).

\section{Results and Discussion}

To achieve the demographic representation, the researcher decided to take in-depth interviews aged between 23 - 34 years age group. Each interview took 30 - 45 minutes. The demographic profile of the respondent is summarized in Table 1.

\subsection{Role of Mall Culture in Our Lives Today}

Impression of the Mall: Respondents were interviewed and asked about their preference regarding what comes to their minds when they think about malls and later they were asked to elaborate on their choices. Common themes have been listed out of the interviews, including the narratives from the respondents. These themes are as below:

Convenience: In the mind of younger shoppers, Convenience of shopping under one roof was considered the most important factor as mentioned by 59.3\% respondents because they consider malls, as a one shop stop/destination with all facilities, cleanliness, variety of stores, movies, food, shopping, playing area for kids, and centralised air conditioning. $14.3 \%$ respondents felt that malls 
Table 1. Demographic profile.

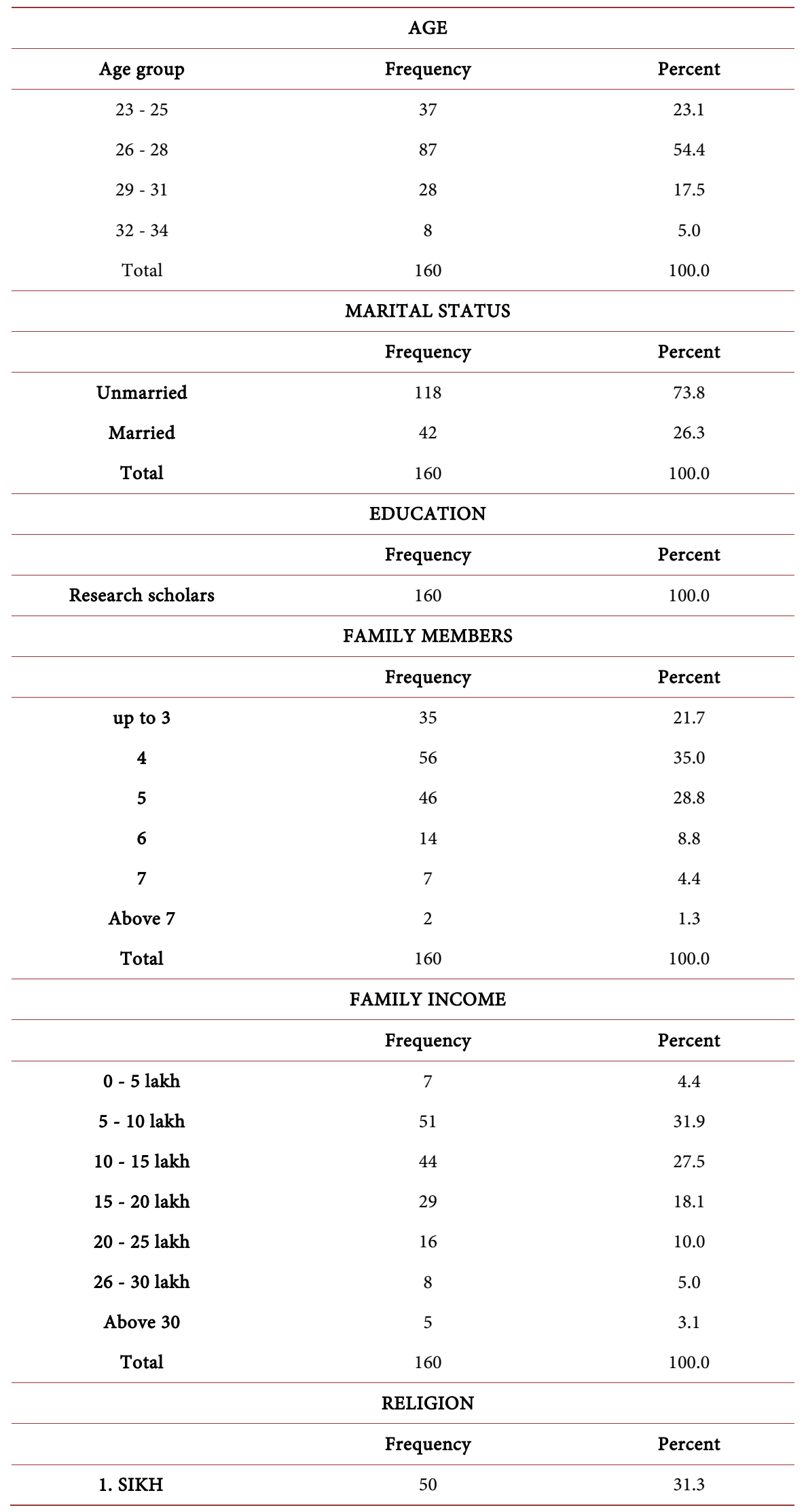


Continued

\begin{tabular}{|c|c|c|}
\hline 2. HINDU & 104 & 65.0 \\
\hline 3. others & 6 & 3.8 \\
\hline Total & 160 & 100.0 \\
\hline \multicolumn{3}{|c|}{ CASTE } \\
\hline & Frequency & Percent \\
\hline 1. Arora/Khatri & 24 & 15.0 \\
\hline 2. Bania & 16 & 10.0 \\
\hline 3. Brahmin & 23 & 14.4 \\
\hline 4. Jat & 39 & 24.4 \\
\hline 5. Rajput & 25 & 15.6 \\
\hline 6. others & 33 & 20.6 \\
\hline Total & 160 & 100.0 \\
\hline \multicolumn{3}{|c|}{ FAMILY TYPE } \\
\hline & Frequency & Percent \\
\hline Nuclear & 104 & 65.0 \\
\hline Joint & 56 & 35.0 \\
\hline Total & 160 & 100.0 \\
\hline \multicolumn{3}{|c|}{ DEPARTMENT } \\
\hline & Frequency & Percent \\
\hline Sciences & 83 & 51.9 \\
\hline Arts & 77 & 48.1 \\
\hline Total & 160 & 100.0 \\
\hline \multicolumn{3}{|c|}{ RESIDENCE } \\
\hline & Frequency & Percent \\
\hline HOSTLER & 93 & 58.1 \\
\hline DAYSCHOLAR & 67 & 41.9 \\
\hline Total & 160 & 100.0 \\
\hline \multicolumn{3}{|c|}{ PLACE OF BIRTH } \\
\hline & Frequency & Percent \\
\hline Chandigarh & 23 & 14.4 \\
\hline Delhi & 3 & 1.9 \\
\hline Himachal Pradesh & 29 & 18.1 \\
\hline Haryana & 12 & 7.5 \\
\hline Jammu \& Kashmir & 7 & 4.4 \\
\hline Punjab & 76 & 47.5 \\
\hline Others & 10 & 6.2 \\
\hline Total & 160 & 100.0 \\
\hline
\end{tabular}


are more time and money saving as one can visit many stores one at a time and all work can be done at the same time and place. Shopping is more comfortable in malls as one does not have to roam in sun; there are no weather worries and they make life easy as mentioned by $17.5 \%$ respondents. The researcher did not get reply from rest of the respondents in this context.

Choice: The respondents agreed that malls offer lots of choices through a variety of stores, anchor stores and food courts. Some of the respondents mentioned that malls provide cuisines for all types of customers. A lot of variety and a lot of brands can be accessed as mentioned by $40.6 \%$ of the respondents. $3.75 \%$ of the respondents said that sometimes one finds brands in a mall, that you haven't heard of. Moreover malls provide unlimited options to buy. One get all types of products ranging from cheap to expensive products while rest of the respondents did not reply.

Awareness: Malls have brought brand awareness and brand consciousness among the youth. As mentioned by $11.8 \%$ respondents, malls have also increased fashion consciousness as one gets aware when one see trendy people around. $10 \%$ of the respondents mentioned that they feel comfortable in the mall as they can check the latest and unique styles and can compare the quality, variety, prices, offers and comfortability of each brand. Moreover malls help in updating their knowledge regarding new designs and new brands available.

Crowd and Congested: $13.7 \%$ of the respondents mentioned "crowds", "confused" or "congested feeling" in shopping malls. Because of constant crowd, the malls give a congested feeling, they seem to be closed and crowded. The respondents especially expressed concerns regarding the crowds during festivals. They felt the environment very messy with all the products kept crumbled together instead of being properly displayed. One gets confused with lot of options and brands. $4.3 \%$ of the respondents believed that excess time and money got wasted in buying useless things; Products that one does not need to buy. Many studies also elaborated that crowding has a negative influence on atmospheric perceptions, as they give rise to negative emotions like irritation, unhappiness (Eroglu \& Machleit, 1990; Hui \& Bateson, 1991; Machleit \& Eroglu, 2000).

Ambience: $16.2 \%$ respondents appreciated the positive aesthetics of the malls such as attractive exteriors, pleasant colors, natural entry with flowers, spacious, good architecture, clean atmosphere, well equipped and so on.

Hedonic shopping: Respondents also revealed how they use malls for purposes other than making purchases such as socialisation, family gatherings, escapism, recreation and socialisation. $48.7 \%$ respondents believed that one gets to spend leisure time in malls. It is a recreational activity going to malls; a good place to han gout with friends and family and a good socialisation place for family get together. Malls are for browsing, window shopping, party, entertainment, food, games, and fun with friends and are stress relievers. 
A respondent remarked that she liked to have classy casual latest fashion clothes. She said she could not tolerate boring environment. She felt comfortable in the mall. She liked to check the latest and unique styles in a range of brands. She could get an idea about the prices could easily compare the quality, and could get latest variety in a mall. Even if tired, she finds relaxation, entertainment, recreation, aesthetics and air conditioning. She found Mall environment to be cool as one gets aware about the quality of brands and can compare the comfortability of each brand. (Age 27 years, unmarried Hindu girl from Punjab)

Tauber (1972) also mentioned in his study that cinemas, exhibitions, live events, restaurants, theme areas and fitness spaces provide people a space to talk, meet friends, have leisure time and relax with families in a safe environment without weather worries.

Convenience One gets variety of products under one roof. Khana, pina, biscuit, bakery (food, drinks, biscuit, bakery) all under one roof along with safe parking. One can have coffee after the movie, all entertainment in one go. Age 26/unmarried Sikh/Nuclear family/Hostler/Arts faculty.

Choice Malls are better; one would get variety of brands, and would get cheapest products to the most expensive products under one roof along with air conditioning, food court also. Age 26/unmarried/Hindu Rajput,/Joint family/ Hostler/Science faculty.

Aesthetics Malls are very spacious, have very good architecture with interiors and greenery appeals us. Age 28/Buddhist/married/Hindu/Nuclear family/Day scholar/Science faculty.

Crowded

Because of constant crowd, the malls gives conjusted and messy feeling as all the products get crumbled when you visit mall in the evenings or during festivals. Age 27/Unmarried/Muslim/Nuclear family/Hostler/Arts faculty.

Hedonic We prefer to visit mall with both family and friends for shopping, watching movies shopping and having fun with them. Malls are for browsing, window shopping, party, entertainment, food, games, fun with friends and are stress relievers. Age 26/Hostler/Khatri Sikh/Unmarried/Nuclear family/Science faculty.

Mall Culture: When the respondents were interviewed regarding the impact of malls on their lifestyle. 82 respondents out of 160 used the words modernisation, westernisation, stylish cultural diffusion, snob factor, show off, brand consciousness, brand culture and so on.

Some of the important narratives and cases are summarised as under:

"Mall culture has brought modernisation and westernisation"

"It has brought a stylish cultural diffusion"

"Malls have hit the day to day psychology"

"Snob factor and show off has increased"

"Mall culture has changed my style and personality"

"Mall culture has promoted our privacy"

"Mall culture has brought fun factor in our lives"

"Mall culture has actually twisted the culture; we are now actually spending on worthless products"

Some of the cases are discussed and this very well shows the impact of malls 
on young shoppers (aged between 23 - 34).

Aged 30, married mentioned that

"Mall culture is fast catching up in India and is replacing the traditional retail sector. It is a means of getting almost all the things one need under one roof. It saves one from going for shopping in the hot summers or cold winters or rainy season. It's not only a place for shopping but also provides means of entertainment and rejuvenation. Although it has made the retail industry an organised sector but it is eating up on the small retailers and shoppers which is worrisome"

Aged 27, unmarried justified that

"Mall culture has upgraded our lifestyle however it has added additional stress to maintain that level. For me it has proved a blessing as one can shop for the best brands under one roof

Aged 28, unmarried said that

"I am not so trendy regarding mall culture, when it comes to high class or status function, then I go and buy clothes from malls"

Aged 29, married mentioned that

"Mall culture is to stay abreast with the generation and enjoy work life balance in a carefree neat and clean environment"

Aged 28, married said that

"Mall culture plays an important role as we visit malls with our families on weekends to watch movies, It caters to all age groups. It makes a bonding within the family (Shopping and entertainment). Being in mall enhances your standard and it has become a trend to visit a mall'

Aged 25, unmarried felt some negative aspects related to mall culture and mentioned that

"Mall culture has brought international brands, even as a social scientist the people who buy has become very high headed. Prices are too high. Snob factor has come into society. So I did not like mall culture"

\subsection{Shopping Behaviour of Young Consumers}

In our examination of the mall, the researcher investigated the following aspects: Total number of hours on shopping, preference of shopping day and shopping time by young consumers. We also examined the average expenditure incurred per trip.

Hours spent in shopping: This included the total hours or time contributed towards shopping.

Figure 1 shows the number of hours spent on shopping at the malls by the respondents. The findings reveal that the maximum percentage of customers (32.5\%) spent about 2 - 3 hrs. Almost about 22.5\% of the shoppers spend about 3 - 4 hrs. Further, $16.3 \%$ of the shoppers spent less than 2 hrs. $15.6 \%$ and $13.1 \%$ of the shoppers spent about 4 - 5 hrs and more than 5 hours respectively.

Narahari \& Kuvad (2017) conducted a study on purchase behaviour in shopping malls in Gujarat (Bhavnagar) and found that $50 \%$ of the women spend a good time i.e. 2 - 3 hours when they visit malls. 
It is concluded from the data that maximum percentage (32.5\%) of respondents spend about $2-3 \mathrm{hrs}$ and the least percentage (13.1\%) of the respondents spend more than 5 hours shopping in the malls.

Shopping day preference: Shopping day preference analysed the preference of weekend or weekdays or other holidays by the respondents.

Figure 2 showed shopping day preference by the respondents. The data revealed that the maximum percentage $(61.9 \%)$ of respondents preferred to visit malls on weekend. $20.6 \%$ of the respondents did not care about the day of visit. Whereas, only, 5.6\% of the respondents preferred weekdays for visits to malls. Moreover, only $5.1 \%$ of the respondents preferred holidays for visits to malls.

Henceforth, only $3.1 \%$ preferred only weekend and other holidays whereas, $1.9 \%$ percent of the respondents preferred weekday and weekend respectively.

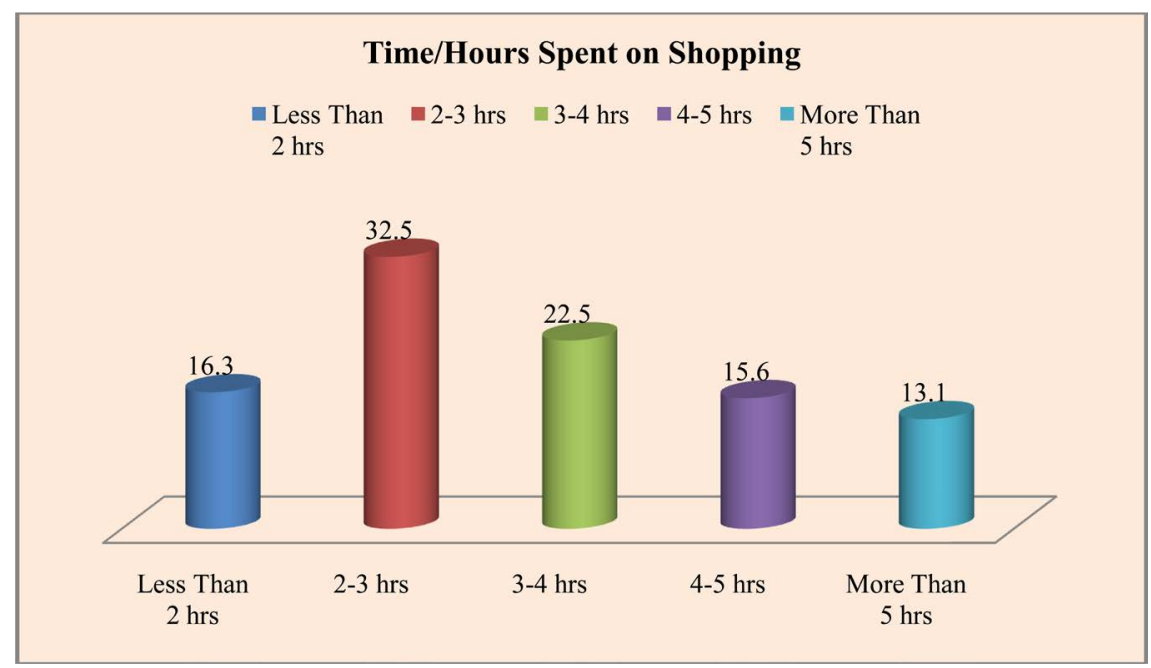

Figure 1. Time/Hours spent in shopping.

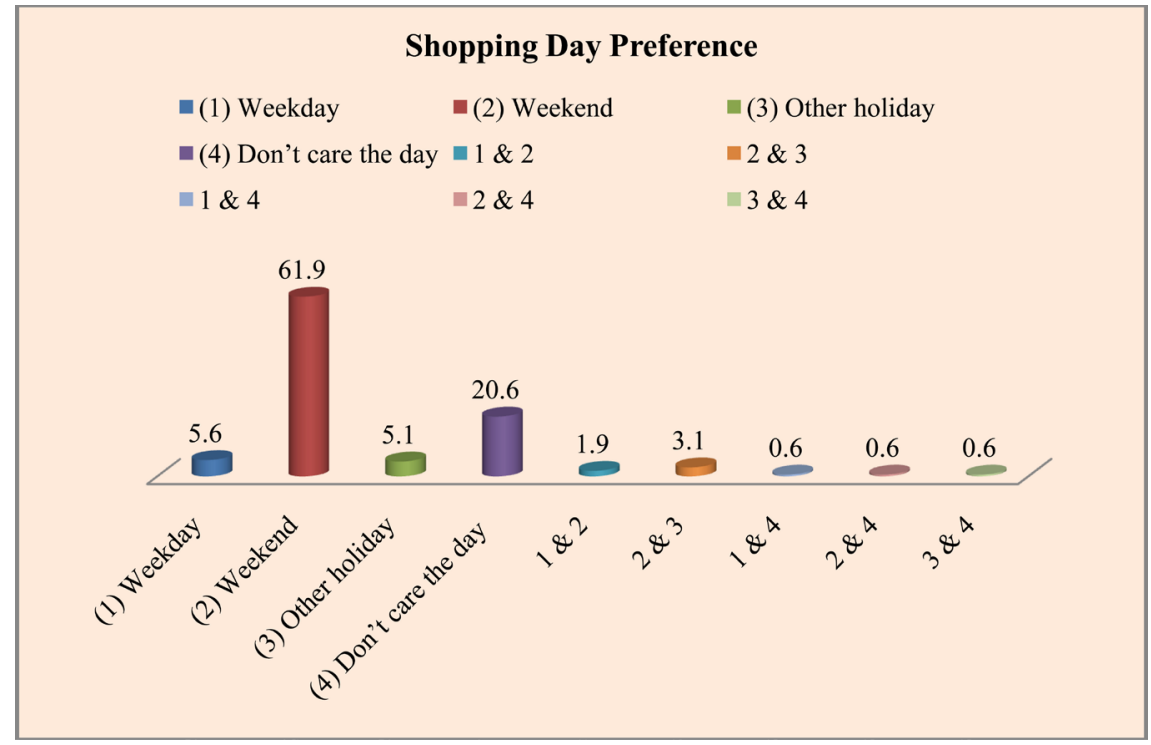

1. Weekday; 2. Weekend; 3. Other holidays; 4 . Don't care about the day of visit.

Figure 2. Shopping day preference. 
Lekshmi \& Jawahar (2012) analysed the same trend and also preferred weekends (61.2\%) for shopping.

One of the respondents (Age24/Hindu/Brahmin/Unmarried/Arts/Nuclear family/Uttarakhand),

"We prefer weekdays for shopping as weekends are crowded with rush as due to new movie releases"

Whereas the other respondent (Age28/Sikh/Khatri/Married/Science/Nuclear family/Jammu \&Kashmir), preferred weekend.

"She said, we are free on weekends, and one would find many events, shows, carnivals being carried on in the malls to attract shoppers on weekends".

It can be concluded from the above findings that weekends are preferred over weekdays and other holidays as most of the respondents are free on weekends and as malls organise events, exhibitions, fashion shows, movie releases on weekends, so these factors attract shoppers towards these activities and they prefer weekends.

Preference of shopping time: It identified the preference of shopping time by the respondents.

Figure 3 showed the preference of shopping time. The output unfolds that maximum percentage of respondents $(31.9 \%)$ preferred to shop at any suitable time. Whereas $23.8 \%$ and $23.1 \%$ preferred timings $(3-6)$ and $(6-9)$. Henceforth, only $10 \%$ of the respondents preferred timings (12 - 3). Only $1.9 \%$ of the respondents preferred morning time $(9$ - 12).

However, it can be intercepted from the findings that evening timings were preferred by maximum number of respondents as it can be evaluated that as the respondents are free in the evenings and wanted to relax from their busy schedule, so preferred shopping in the evenings.

Average amount spend on each visit: This factor analysed the average amount spent by shoppers on each visit.

Figure 4 showed the amount spent on each visit. $22.5 \%$ of the respondents

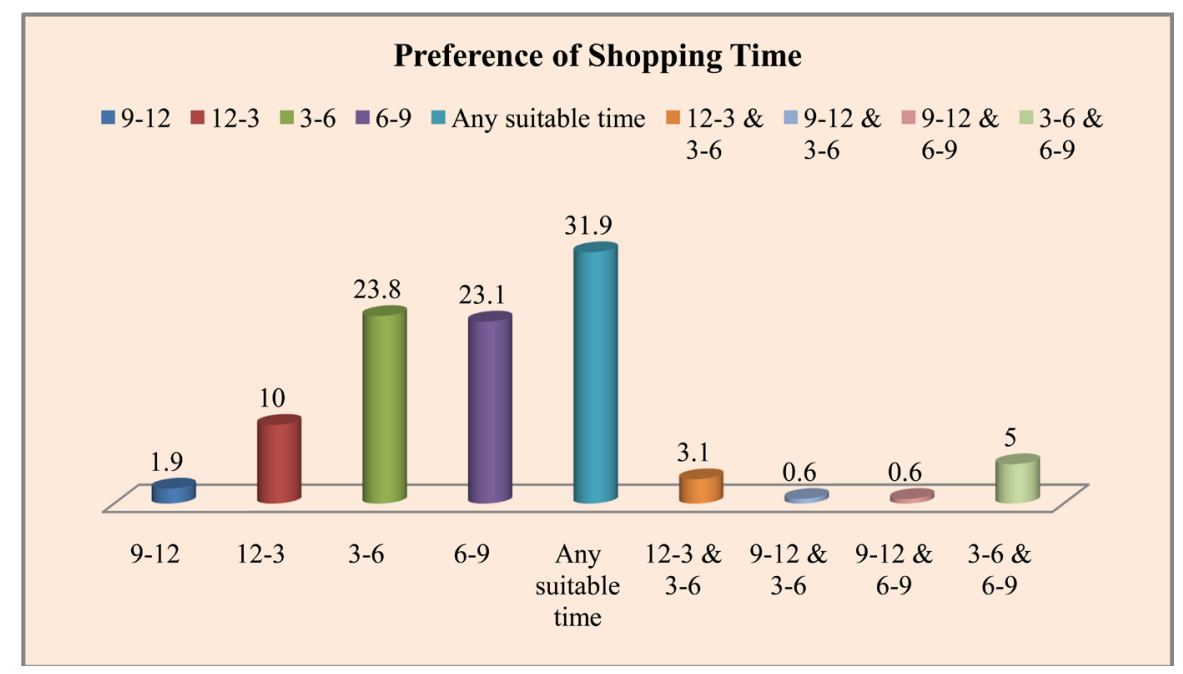

Figure 3. Preference of shopping time. 


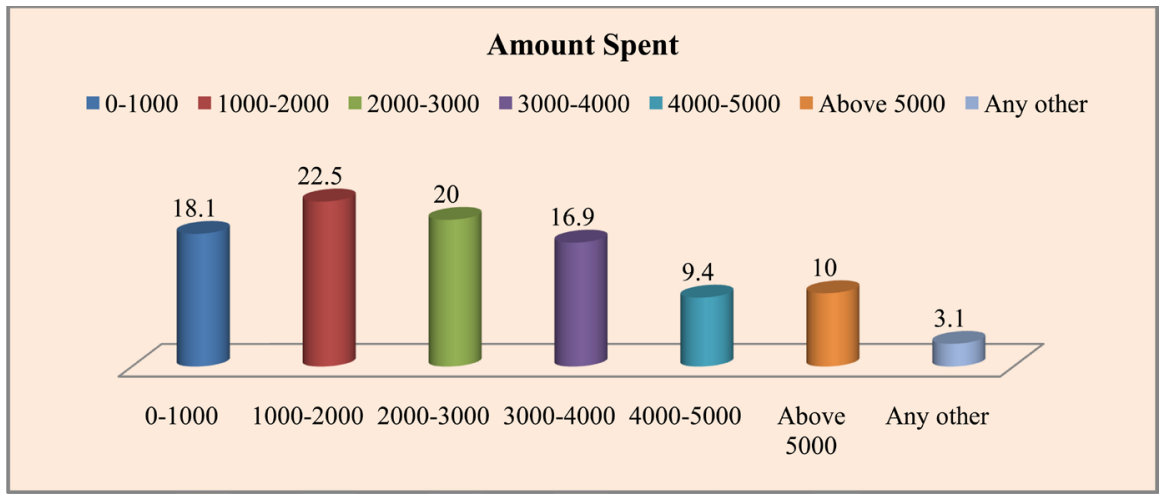

Figure 4. Average amount spent on each visit.

spend less than 2000 on their every visit. Moreover, $20 \%$ of the respondents spend up to 3000 on their every visit. However $18.1 \%$ of the respondents spend less than 1000 on their every visit. Furthermore, $16.9 \%$ and $10 \%$ of the respondents spend up to 4000 and above 5000 on their every visit respectively. A very less percentage $(3.1 \%)$ of respondents visited mall for other purposes or spend according to their need.

According to a study conducted by EYE Mall Shopper Behaviour Study (2015), in this study, $39 \%$ of the respondents spend more than $100 \$(6375)$ on each visit, as compared to the present study, it is $10 \% .34 \%$ of the respondents spend (50 - 99 \$) (3204 - 6349), as compared to the present study, it is $(16.9+9.4$ $+10=36.3$ ) which is a somewhat similar percentage.

However, $24 \%$ of the respondents spend about (20 - 49 \$) (1283 - 3143). It is $45.5 \%$ as compared to the present study, however just $4 \%$ of the respondents spend less than 20 \$ (1283) whereas the results interpreted in our study are different, it is $18.1 \%$.

\subsection{Crux of the Shopping Behaviour of Young Consumers with Regards to Different Variables}

Figure 5 represents the Demographic variables that were researched to study the preference of the respondents towards Shopping at Malls. Factors that motivated them to shop, number of hours they spent at shopping, shopping day and time preferred along with the expenditure spent on shopping were analysed.

Age Factor: In comparison to all age groups, the respondents in the bracket of 32 - 34 years spent more than 5 hours in shopping Malls. The same percentage i.e. $37.5 \%$ also spent $2-3 \mathrm{hrs}$ in shopping at the malls. It is assumed that this is the age when respondents are already married and need to go to malls to shop for requirements of the family.

Family Income: $57.1 \%$ of the respondents whose family income was less than 5 lakhs spent less than 2 hours on shopping in comparison to other income groups. $60 \%$ of the respondents whose income was more than 30 lakhs spent 2 3 hrs on shopping.

Marital Status: The married respondents were seen to prefer shopping at the 


\begin{tabular}{|c|c|c|c|c|c|c|c|c|c|c|c|c|c|c|c|c|}
\hline \multirow[t]{2}{*}{ Variables } & & \multirow{2}{*}{$\begin{array}{l}\text { Age } \\
23-25\end{array}$} & \multirow{2}{*}{$\begin{array}{l}\text { Age } \\
32-34\end{array}$} & \multicolumn{2}{|l|}{ Income } & \multicolumn{2}{|c|}{ Marital status } & \multicolumn{3}{|l|}{ Religion } & \multicolumn{2}{|l|}{ Family type } & \multicolumn{2}{|l|}{ Stream } & \multicolumn{2}{|l|}{ Residence } \\
\hline & & & & 0 - 5 lakhs & $\begin{array}{l}\text { Above } \\
\text { Rs.30 } \\
\text { lakhs }\end{array}$ & $\begin{array}{l}\text { Unmarri } \\
\text { ed }\end{array}$ & Married & Hindu & Sikh & others & Nuclear & Joint & Science & Arts & $\begin{array}{l}\text { Day } \\
\text { Scholar }\end{array}$ & Hostlers \\
\hline $\begin{array}{l}\text { Hours spent } \\
\text { in shopping }\end{array}$ & $\begin{array}{l}2-3 \\
\text { hours }\end{array}$ & $\begin{array}{l}2-3 \\
\text { hours }\end{array}$ & $\begin{array}{l}\text { More } \\
\text { than } 5 \\
\text { hours }\end{array}$ & $\begin{array}{l}\text { Less than } \\
2 \text { hours }\end{array}$ & $\begin{array}{l}2-3 \\
\text { hours }\end{array}$ & $\begin{array}{l}\text { Less } \\
\text { than } 2 \\
\text { hours }\end{array}$ & $\begin{array}{l}2-3 \\
\text { hours }\end{array}$ & $\begin{array}{l}2-3 \\
\text { hours }\end{array}$ & $\begin{array}{l}\text { More } \\
\text { than } 5 \\
\text { hours }\end{array}$ & $\begin{array}{l}\text { More } \\
\text { than } 5 \\
\text { hours }\end{array}$ & $\begin{array}{l}\text { More than } \\
5 \text { hours }\end{array}$ & $\begin{array}{l}2-3 \\
\text { hours }\end{array}$ & $\begin{array}{l}2-3 \\
\text { hours }\end{array}$ & $\begin{array}{l}\text { More } \\
\text { than } 5 \\
\text { hours }\end{array}$ & $2-3$ hours & $\begin{array}{l}\text { More than } \\
5 \text { hours }\end{array}$ \\
\hline $\begin{array}{l}\text { Shopping } \\
\text { day } \\
\text { preference }\end{array}$ & Weekend & weekend & $\begin{array}{l}\text { Don't } \\
\text { care } \\
\text { about the } \\
\text { day }\end{array}$ & Weekday & Weekend & $\begin{array}{l}\text { Other } \\
\text { holidays }\end{array}$ & $\begin{array}{l}\text { Weekday, } \\
\text { Weekend } \\
\& \text { don't } \\
\text { care }\end{array}$ & Weekend & Weekday & Weekend & Weekday & Weekend & $\begin{array}{l}\text { Weekend } \\
\text { and other } \\
\text { holidays }\end{array}$ & Weekday & $\begin{array}{l}\text { Weekend } \\
\text { and } \\
\text { Weekday }\end{array}$ & $\begin{array}{l}\text { Other } \\
\text { holidays \& } \\
\text { Do not } \\
\text { care about } \\
\text { the day }\end{array}$ \\
\hline $\begin{array}{l}\text { Preference } \\
\text { of shopping } \\
\text { time }\end{array}$ & $\begin{array}{l}\text { Any } \\
\text { suitable } \\
\text { time } \\
(31.9 \%)\end{array}$ & Morning & $\begin{array}{l}12-3,3- \\
6\end{array}$ & $12-3$ & $3-6$ & $\begin{array}{l}12-3, \\
3-6, \\
\text { Any } \\
\text { suitable } \\
\text { timings }\end{array}$ & $6-9$ & $\begin{array}{l}\text { Any } \\
\text { suitable } \\
\text { timings }\end{array}$ & $6-9$ & $\begin{array}{l}\text { Any } \\
\text { suitable } \\
\text { timings }\end{array}$ & $\begin{array}{l}9-12,12- \\
3, \text { Any } \\
\text { suitable } \\
\text { timings }\end{array}$ & $\begin{array}{l}3-6,6- \\
9\end{array}$ & $\begin{array}{l}9-12 \\
12-3 \\
6-9\end{array}$ & $\begin{array}{l}3-6 \text {, } \\
\text { Any } \\
\text { suitable } \\
\text { timings }\end{array}$ & $12-3,6-9$ & $\begin{array}{l}9-12 \text {, any } \\
\text { suitable } \\
\text { timings }\end{array}$ \\
\hline $\begin{array}{l}\text { Average } \\
\text { amount } \\
\text { spent }\end{array}$ & $\begin{array}{l}\text { Rs.1000- } \\
2000\end{array}$ & $\begin{array}{l}\text { Till Rs. } \\
4000\end{array}$ & $\begin{array}{l}\text { Above } \\
\text { Rs.5000 }\end{array}$ & $\begin{array}{l}\text { Till } \\
\text { Rs.2000 }\end{array}$ & $\begin{array}{l}\text { Till } \\
\text { Rs.4000 }\end{array}$ & $\begin{array}{l}\text { Till Rs. } \\
3000\end{array}$ & $\begin{array}{l}\text { Above } \\
\text { Rs. } 5000\end{array}$ & $\begin{array}{l}\text { Till Rs. } \\
2000\end{array}$ & $\begin{array}{l}\text { Above } \\
\text { Rs.5000 }\end{array}$ & $\begin{array}{l}\text { Till } \\
\text { Rs.5000 }\end{array}$ & $\begin{array}{l}\text { Till } \\
\text { Rs.5000 }\end{array}$ & $\begin{array}{l}\text { Above } \\
\text { Rs. } 5000\end{array}$ & $\begin{array}{l}\text { Till } \\
\text { Rs.5000 } \\
\text { and } \\
\text { above }\end{array}$ & $\begin{array}{l}\text { Till } \\
\text { Rs.4000 }\end{array}$ & $\begin{array}{l}\text { Till } \\
\text { Rs.5000 }\end{array}$ & $\begin{array}{l}\text { Above } \\
\text { Rs.5000 }\end{array}$ \\
\hline
\end{tabular}

Figure 5. Crux of the shopping behavior.

malls for up to 2 - 3 hours. Unmarried respondents spent more than 5 hours on shopping.

Caste Factor: Respondents from Bania Caste (25\% and 50\%) spent up to 2 or between 2 - 3 hours at shopping malls respectively. This caste is generally into business or in high wage employment. They probably believe in making the best use of their time and do not prefer spending too much time at the malls. Khatri and Rajput Caste are known to be more gregarious and social in nature. For this reason perhaps up to $40 \%$ of them were seen to spend larger hours i.e. up to 4 - 5 hours in the malls.

Religion Factor: Respondents from Sikh and other religions spent more than 5 hours on shopping. Sikh community is the landlord community so it seems they have more time to spend at the malls. Since occupation is seasonal, they probably had more time for leisure and entertainment. Hindus were seen to spend just 2 - 3 hrs on shopping (36.5\%). They were lesser inclined towards spending extended hours for shopping in malls.

Family type: Respondents from the Nuclear families could spend more time in the malls. They probably had lesser home chores and responsibilities and could therefore spend more time in the malls. A larger percentage of respondents (39.3\%) from Joint families spent just $2-3$ hours at the malls.

Academic stream: Maximum respondents i.e. $38.6 \%$ belonging to science stream spent up to 3 hours on shopping. Student respondents from Arts Stream had more relaxed schedule as compared to student respondents from science stream respondents, so they tend to spend more than 5 hours on shopping.

Place of Residence: Day scholars preferred to spend maximum up to 4 hours on shopping. Hostlers tend to spend up to and more than 5 hours on shopping. So it can be analysed that respondents who are hostlers spend more time on shopping at the malls. They have the freedom and time to visit the malls for en- 
tertainment, socialising with friends, eating out and shopping.

Preference for "Day of Shopping": Data revealed that the maximum percentage $(61.9 \%)$ of respondents preferred to visit malls on weekends.

Age Factor: Weekdays were also preferred by all the age groups except the respondents in the age group of 32 - 34 who did not prefer to shop on weekdays at all. These respondents preferred to shop on holidays and some even did not care about the days of shopping; they shopped as and when required.

Family Income: Respondents whose income was in the bracket of Rs. 0 - 5 lakhs preferred to shop on weekdays. Respondents falling in the income bracket of Rs. 5 - 10 lakhs, Rs. 10 - 15 lakhs and Rs. 20 - 25 lakhs preferred other holidays along with shopping on weekends. $100 \%$ of respondents whose income is above Rs. 30 lakhs preferred to shop on weekends.

Marital Status: The percentage of married respondents shopping on weekdays (7.1\%) and weekends (64.3\%) was more as compared to unmarried respondents. Unmarried respondents preferred to shop on other holidays.

Religion Factor: $65.4 \%$ of Hindus preferred weekends as their first choice as compared to $54 \%$ Sikhs. $8 \%$ Sikhs preferred weekdays and $6 \%$ Sikhs preferred other holidays for shopping in comparison to Hindu respondents.

Family Type: $66.1 \%$ of the respondents who belonged to Joint Family preferred weekends and $7.1 \%$ preferred other holidays for shopping. Weekdays were preferred by respondents belonging to Nuclear Family. 24\% of the respondents belonging to Nuclear Family did not care about the day of shopping.

Academic stream: Respondents who enrolled in Science Stream preferred weekends and other holidays for shopping while these enrolled in Arts stream preferred weekdays.

Residence: Non hostlers preferred weekends (64.2\%) and weekdays (6\%) as compared to hostlers. However, hostlers preferred other holidays and some did not even care about the day of shopping as compared to $19.4 \%$ non hostlers.

Preference for Shopping Time: Maximum respondents preferred to shop at any suitable time.

Age Factor: $37.8 \%$ and $33.3 \%$ of the respondents in the age group of $23-25$ and 26 - 28 respectively preferred to shop at timings suitable to them as per schedule. $35.7 \%$ of the respondents in the age group of 29 - 31 preferred evening time between $6 \mathrm{pm}-9 \mathrm{pm}$. 25\% of the respondents in the age group of $32-34$ preferred to shop between 12 Noon to $3 \mathrm{pm}$, mid evening between $3 \mathrm{pm}$ to $6 \mathrm{pm}$ and at timings suitable to them as per their schedule.

Family Income: Maximum number of respondents in the income group of Rs. 5 - 10 lakhs (35.3\%) and Rs. 26 - 30 lakhs (50\%) preferred to shop at timings suitable to them. $37.5 \%$ and $31 \%$ of the respondents in the income group of Rs. 20 - 25 lakhs and Rs. 15 - 20 lakhs preferred to shop between timings 3 pm to 6 pm and 6 pm - 9 pm respectively. It was further found that only the respondents in the income group of Rs. 10 - 15 lakhs (6.8\%) preferred to shop in the morning hours between 9 am and 12 noon. 
Marital status: $35.7 \%$ of the respondents who were married preferred to shop in the evening between $6 \mathrm{pm}-9 \mathrm{pm}$. Maximum number of unmarried respondents i.e. $33.9 \%$ preferred to shop at a time suitable to them. Moreover none of the married respondents preferred to shop early in the morning.

Religion Factor: Maximum number i.e. 35.6\% of respondents who were Hindus and $50 \%$ of respondents belonging to other religions preferred to shop at timings suitable to them whereas maximum number of respondents who were Sikhs preferred to shop in the evenings between $6 \mathrm{pm}-9 \mathrm{pm}$ and mornings between 9 am to 12 noon.

Family Type: The maximum variation was found where $30.4 \%$ of the respondents belonging to Joint Family preferred to shop in the early evenings between 3 pm to $6 \mathrm{pm}$. More number of respondents belonging to Nuclear Family preferred to shop between 9 am to 12 noon and 12 noon - 3 pm or at a time suitable to them.

Academic stream: Respondents from Science stream preferred to shop between 9 am to 12 noon, 12 noon to $3 \mathrm{pm}$ and $6 \mathrm{pm}$ to $9 \mathrm{pm}$. Respondents belonging to arts stream preferred to shop during early evenings between $3 \mathrm{pm}$ to 6 pm and at timing suitable to them.

Place of Residence: Maximum number of non hostlers (28.4\%) preferred to shop in the evening between $6 \mathrm{pm}$ to $9 \mathrm{pm}$, whereas maximum number of hostlers preferred to shop in the morning and at time suitable to them.

Average amount spent on each visit: It was seen that Maximum respondents spend less than 2000 on their every visit to a Mall.

Age Factor: $25 \%$ of the respondents in the age group of 32 - 34 spent more than 5000 .

Family Income: The maximum respondents i.e. $37.5 \%$ in the income group of 26 - 30 lakhs spend between 3000 - 4000 on their each visit to a mall as compared to those respondents income group of 0 - 5 lakhs where maximum respondents i.e. $57.1 \%$ of the respondents spent between $1000-2000$.

Marital status: The maximum variation was found in case of spending above 5000, 16.7\% married respondents and 7.6\% unmarried respondents spent more than Rs. 5000/- during each visit to a mall. $21.2 \%$ unmarried respondents spent up to 1000 on their each visit as compared to $9.5 \%$ married respondents. Thus output unwinds married respondents spent more as compared to unmarried respondents.

Religion Factor: Respondents who were Hindus spent up to 2000/- on each visit while respondents who were sikhs spent above 5000 on each visit.

Family Type: Respondents belonging to Joint families spent about 2.5 times more than respondents belonging to Nuclear families.

Faculty: 29.9\% respondents enrolled in Arts stream spent up to 2000 on their each visit to a Mall. Maximum respondents enrolled in Science stream spent up to 5000 on each visit.

\subsection{Evaluation of Mall Attributes}

Respondents discussed various attributes that they felt are important to them. 
Various aspects were highlighted by the respondents. The following mall attributes were considered important to young shoppers.

Sitting arrangement: $40.6 \%$ respondents felt that there is a requirement for sitting arrangement on all floors while one roam in malls or has refreshment, one need sitting corners. Further, they elaborated that there are less number of "Sofas" (Seats) and they are always occupied. Even the older people who accompany their kids can sit comfortably as their kids are busy in shopping.

Basic necessities: $16.2 \%$ respondents felt that water dispensers are required in the shopping malls as one has to buy water for drinking. 3.7\% of the respondents felt that there should be a play area with a caretaker so that mothers can shop comfortably and leave their kids.1.2\% of the respondents felt the need for Gym, $1.2 \%$ respondents felt the need for free mobile charging units, $1.2 \%$ felt the need for shuttle service, $1.2 \%$ felt that there is need for emergency medical facility, $1.2 \%$ felt that there should be online machine for buying clothes, $1.8 \%$ felt the need for clean washrooms, and lastly $1.2 \%$ of the respondents felt that there should be more arrangement for people who are physically handicapped, They believed that Mall facility should cater differently-abled people and it should not be just a show off.

Layout: $6.25 \%$ respondents considered the malls should have E-mapping or more sign boards or assistance to locate a brand, store or washrooms. The respondents focused on the lack of maps and directories that helped shoppers to find their location and they also suggested that maps and directories should be updated when the stores moved in and out. Further the respondents elaborated that stores having sales/discounts should be displayed on LEDS.

Parking: There were mixed reactions regarding the parking in malls. Some of the respondents believed that it is very easy and convenient. $11.8 \%$ respondents had complaints about parking in shopping malls. $5.6 \%$ of the respondents elaborated on the charges of parking as they felt parking charges should be reduced as this would further increase footfall in malls.

Escalators/lifts: Most of the respondents were satisfied with the Escalators/ lifts in the shopping malls. But still 3.75\% of the informants complained about the lifts, they suggested that there should be more number of lifts, and malls should have plain ramp.

One of the respondents mentioned that her mother felt scared to walks on escalators. Malls should have a provision of plain ramps as well.

Security: Most of the respondents who were interviewed expressed high confidence in mall security but $2.5 \%$ of the respondents complained about security issues in malls.

Atmosphere: Most of the informants appreciated the overall aesthetics of the mall. Malls in Chandigarh are sufficient in providing facilities from old age to kids. $11.2 \%$ respondents felt that Malls are complete in all aspects. Some of the respondents felt that recreational activities for old people should be there in the mall as they do not prefer to watch movie. $3.1 \%$ of the respondents were con- 
cerned about the fun zone for kids and sport games. However, $1.2 \%$ of the respondents suggested that there should be live concerts and more promotions of new launches of brands.

Book Browsing section: Most of the respondents expressed satisfaction with the services provided by malls, but $8.1 \%$ respondents expressed a need for book browsing section. They further elaborated that malls should have book stores with good collection of books, reading area and newsstand.

Brands: Many of the respondents felt the need for more brands, $7.5 \%$ respondents gave different views. Some expressed that there should be restaurants on every floor; some others mentioned that there should be need for more Chinese restaurants, more ice cream parlours, some also wanted more international brands to be introduced. Some of them were of the opinion that electronic equipment stores should be introduced along with those small stalls selling local products in the walkways of the malls. This would further increase customer footfall.

Customer service: Most of the respondents were satisfied with the customer service in shopping malls. Further 5.6\% respondents expressed that Salesperson should be there to guide the potential customers, but they should not intervene in shopping. The respondents said that in some stores, salespersons are very nice and knowledgeable and they actually help one to make a buying decision and close a sale. They also felt that Sales depends upon how friendly the staff is.

Salespersons in branded stores are very sophisticated. They are well dressed and they would show a customer end number of products and do not get irritated. However, local market salespersons of local markets get irritated. Helpful and knowledgeable salesperson certainly help in purchasing products

\section{Summary and Conclusion}

The respondents interviewed in the study have favourable attitude towards shopping malls. Convenience of having everything under one roof, with no weather worries has been considered the most attractive aspect to young consumers. Hedonic aspects such as browsing, window shopping, playing area for kids, space for various shows, exhibitions, spending quality time with families have been ranked as the second important aspects followed by extensive variety of brands/stores, ambience, awareness offered by malls. However, respondents expressed concern regarding crowd on festivals or messy felling when one visited mall in the evening. It is interesting to note that the respondents who were interviewed believed that malls have brought westernisation, modernisation, brand consciousness, brand culture and so on. Various terms were used to identify the presence of Mall culture in our society.

"Malls bring a new shopping culture in our society. I am more conscious about brands, looks, trends and latest fashion"

"Mall culture has brought comfort along with fun rather than going in nature, we prefer malls"

"Mall culture has changed the way of shopping and enjoyment among families 
and friends"

"Mall culture does not affect our social life, but it feels good to have new trend in life"

However, researcher further investigated the shopping behaviour of consumers. Maximum respondents preferred to shop at any suitable time. One of the respondents said that she could spend a whole day at the shopping malls in sector 17; be unmindful of the number of hours she spent there.

A study was conducted by Lekshmi \& Jawahar (2012) in Chennai on the time spent in shopping. It was found that $55.5 \%$ of the respondents spend 2 to $4 \mathrm{hrs}$. This study compares favourably the findings of the present research. $32.5 \%+$ $22.5 \%$, i.e. $55 \%$ respondents in the present study spend between $2-4 \mathrm{hrs}$ in the malls. $28.1 \%$ spend less than $2 \mathrm{hrs}$ as identified by Lekshmi \& Jawaharrani. Also in the present study, just $16.3 \%$ of the respondents spend less than $2 \mathrm{hrs}$. This trend supports the "Emerging Mall Culture" in the society today. It was further analysed that maximum respondents preferred weekend over weekdays. Qualitative study was conducted by Farrag et al. (2010) in Alexandria city centre mall located at the outskirts of city Alexandria desert road, Egypt and the results interpreted were quite similar. Weekends were preferred and teens preferred to shop in the company of their friends and even some of the married women preferred to shop alone and not in the company of their children or husband. The similar trends have been found in the study of El-Adly (2007), where the younger segment i.e. $72 \%$ of the population is less than 40 years of age (who were called demanding shoppers) also preferred weekends for their shopping.

It was interesting to note that a large percentage of shoppers preferred evenings for shopping. The shopping time was also studied by Lekshmi \& Jawahar (2012) but the results intercepted were quite different. In this study 6 - 9 was the most preferred shopping time by $61.9 \%$ respondents, whereas this percentage was the third preferred percentage (23.1\%).

12 - 3 was the timings were the fourth preferred percentage (4.5\%) even in the present study, 12 - 3 timings was the fourth preferred timing by $10 \%$ of respondents. Furthermore, maximum respondents i.e. $22.5 \%$ shoppers spend up to 2000 on their every visit to Mall. However, Demographic variables were researched to study the preference of the respondents towards Shopping at Malls. Sitting area (40.6\%) was considered the most important mall determinant required by shoppers followed by parking issue, Water dispensers, Book browsing section, more brands, shuttle service, and so on.

Though it is convenient to buy everything from one place, I do not like the hassle of finding parking spaces and going through security checks, also searching for stores and recalling their locations is a problem. There should be more sitting areas and guidelines on where to find the stores from (age 29, Unmarried, Ramgaria, Sikh, Chandigarh, Nuclear family).

\section{Significance of the Study}

A study of Shopping Malls is very important for several reasons. The research 
tends to determine the reasons why consumers shop at malls, what are their reasons for shopping at the malls, what are the factors that motivate them to shop at Malls and the amount of time and money they spend when at the Malls. As Anthropology is a holistic study so the researcher has analysed the shopping behaviour of consumers with regard to all demographic factors such as Age, Marital Status, Family Income, Religion, Caste, Family Type, Faculty and Residence of the Respondents.

The present research will contribute to a better understanding of Mall Culture (i.e. the role of malls in daily lives). How the Mall Culture influences the thinking process of consumers. Empirical studies on shopping malls would provide retailers i.e. shopping mall and brand stores information on various variables such as Parking Facilities, Ambience, Location, Perfect Tenant Mix and how these factors contribute to the successful running of Shopping Malls.

Hence, this study would help Shopping Malls would help malls gain a competitive advantage with an effort to attract and retain more customers in the shopping premises.

\section{Conflicts of Interest}

The authors declare no conflicts of interest regarding the publication of this paper.

\section{References}

Arnold, M. J., \& Reynolds, K. E. (2003). Hedonic Shopping Motivations. Journal of Retailing, 79, 77-95. https://doi.org/10.1016/j.ijresmar.2014.03.001

Ashley, B. (1997). Are Malls in America's Future? In Arthur Andersen Retailing Issues Letter (Vol. 9, No. 6). College Station, TX: Texas A\&M University Center for Retailing Studies.

Assael, H. (1987). Consumer Behavior and Marketing Action (3rd ed.). Boston, MA: Kent Publishing Company.

Babin, B. J., Darden, W. R., \& Griffen, M. (1994). Work and/or Fun: Measuring Hedonic and Utilitarian Shopping Value. Journal of Consumer Research, 20, 644-656. https://doi.org/10.1086/209376

Babin, B. J., \& Attaway, J. S. (2000). Atmospheric Affect as a Tool for Creating Value and Gaining Share of Customer. Journal of Business Research, 49, 91-99. https://doi.org/10.1016/S0148-2963(99)00011-9

Berman, B., \& Evans, J. R. (1995). Retail Management (6th ed., p. 95) New York: McMillan Publishing Co. https://doi.org/10.1108/BFJ-11-2016-0567

Berry, L., Seiders, K., \& Grewal, D. (2002). Understanding Service Convenience. Journal of Marketing, 66, 1-17. https://doi.org/10.1509/jmkg.66.3.1.18505

Bird, L. (1997). Huge Mall Bets on Formula of Family, Fun and Games. The Wall Street Journal, B1.

Bloch, P. H., Ridgway, N. M., \& Dawson, S. A. (1994). The Consumer Mall as Shopping Habitat. Journal of Retailing, 70, 23-42. https://doi.org/10.1016/0022-4359(94)90026-4

Bureau of Labour Statistics (2013). https://www.bls.gov/opub/ted/2015/consumer-spending-by-age-group-in-2013.htm 
Carlisle, T. (1997). Gamble by World's Biggest Mall Pays Off. The Wall Street Journal, B1.

Carlson, H. J. (1991). The Role of the Shopping Centre in US Retailing. The International Journal of Retail \& Distribution Management, 19, 13-20. https://doi.org/10.1108/EUM0000000002951

Dholakia, R. R. (1999). Going Shopping: Key Determinants of Shopping Behaviours and Motivations. International Journal of Retail and Distribution Management, 27, 154-165. https://doi.org/10.1108/09590559910268499

Donovan, R. J., \& Rossiter, J. R. (1982). Store Atmosphere: An Environmental Psychology Approach. Journal of Retailing, 58, 34-57.

Donovan, R. J., Rossiter, J. R., Marcoolyn, G., \& Nesdale, A. (1994). Store Atmosphere and Purchasing Behaviour. Journal of Retailing, 70, 198-199. https://doi.org/10.1016/0022-4359(94)90037-X

El-Adly, M. I. (2007). Shopping Malls Attractiveness: A Segmentation Approach. International Journal of Retail and Distribution Management, 35, 936-950. https://doi.org/10.1108/09590550710828245

Eroglu, S. A., \& Machleit, K. A. (1990). An Empirical Study of Retail Crowding: Antecedents and Consequences. Journal of Retailing, 66, 201-221.

EYE Shop Mall Shopper Behaviour Study (2015). http://static1.squarespace.com/static/56001932e4b050f2f62316e3/t/565ca278e4b0acafe1 2c74a6/1448911480432/research+deck_Update_Lo.pdf

Falk, P., \& Campbell, C. (1997). The Shopping Experience. London, Thousand Oaks, CA, New Delhi: Sage Publications. https://trove.nla.gov.au/version/46663392

Farrag, D. A., EL Sayed, I. M., \& Belk, R. W. (2010). Mall Shopping Motives and Activities: A Multi-Method Approach. Journal of International Consumer Marketing, 22, 95-115. https://doi.org/10.1080/08961530903476113

Feinberg, R. A., \& Meoli, J. (1991). A Brief History of the Mall. In R. H. Holman, \& M. R. Solomon (Eds.), NA-Advances in Consumer Research (Vol. 18, pp. 426-427). Provo, UT: Association for Consumer Research.

Finn, A., \& Louviere, J. (1990). Shopping Centre Patronage Models: Fashioning a Consideration Set Segmentation Solution. Journal of Business Research, 21, 259-275. https://doi.org/10.1016/0148-2963(90)90032-9

Fram, E. H., \& Axelrod, J. (1990). The Distressed Shopper. American Demographics, 12, 44-45.

Gentry, J. W., \& Burn, A. C. (1977). How Important Are Evaluative Criteria in Shopping Centre Patronage? Journal of Retailing, 53, 73-86.

Gruen, V., \& Smith, L. (1960). Shopping Town USA: The Planning of Shopping Centres. New York: Van Nostrand Reinhold.

Hernandez, T., \& Jones, K. (2005). Downtowns in Transition: Emerging Business Improvement Area Strategies. International Journal of Retail and Distribution Management, 33, 789-805. https://doi.org/10.1108/09590550510629392

Holbrook, M. B. (1999). Introduction to Consumer Value: A Framework for Analysis and Research. London: Routledge \& Kegan Paul. https://doi.org/10.4324/9780203010679.ch0

Hook, S. (1989). Development of the Store Image Construct: A Review of Literature from 1958 to the Present. In P. Bloom et al. (Eds.), Enhancing Knowledge Development in Marketing (p. 99). Chicago, IL: American Marketing Association.

Howard, E. (2007). New Shopping Centres: Is Leisure the Answer. International Journal 
of Retail and Distribution Management, 35, 661-672. https://doi.org/10.1108/09590550710758649

Howard, E. B. (1993). Assessing the Impact of Shopping-Centre Development: The Meadow Hall Case. Journal of Property Research, 10, 97-119. https://doi.org/10.1080/09599919308724084

Hui, M. K., \& Bateson, J. E. G. (1991). Perceived Control and the Effects of Crowding and Consumer Choice on the Service Experience. Journal of Consumer Research, 18, 174-184. https://doi.org/10.1086/209250

India Consumer Spending (2004-2017). https://tradingeconomics.com/india/consumer-spending

Kaufman, C. F. (1996). A New Look at One-Stop Shopping: A TIMES Model Approach to Matching Store Hours and Shopper Schedules. Journal of Consumer Marketing, 13, 4-52. https://doi.org/10.1108/07363769610147848

Knight, F. (2015). https://content.knightfrank.com/research/317/documents/en/india-retail-report-2646. pdf http://www.icmrindia.org/casestudies/catalogue/Business\%20Reports/BREP047.htm

Kowinski, W. S. (1985). The Mailing of America. New York: William Morrow and Company, Inc.

Laroche, M., Teng, L., Michon, R., \& Chebat, J. C. (2005). Incorporating Service Quality into Consumer Mall Shopping Decision Making: A Comparison between English and French Canadian Consumers. Journal of Services Marketing, 19, 157-163.

Lekshmi, R. S., \& Jawahar, R. (2012). Shopper Behaviour in Malls. Asian Academic Research Journal of Multidisciplinary, 1, 52-63. https://doi.org/10.1108/08876040510596830

Loudon, D. L., \& Bitta, A. J. D. (1993). Consumer Behavior: Concepts and Applications (4th ed.). New York: McGraw-Hill.

Lui, K. F. (1997). Shopping Behavior in Kuala Lumpur Shopping Malls. BA Thesis, Malaysia: University of Putra.

Machleit, K. A., \& Eroglu, S. A. (2000). Describing and Measuring Emotional Response to Shopping Experience. Journal of Business Research, 49, 101-111. https://doi.org/10.1016/S0148-2963(99)00007-7

Millan, E. S., \& Howard, E. (2007). Shopping for Pleasure? Shopping Experiences for Hungarian Consumers. International Journal of Retail and Distribution Management, 35, 474-487. https://doi.org/10.1108/09590550710750340

Narahari, A. C., \& Kuvad, D. (2017). Customer Behaviour towards Shopping Malls-A Study in Bhavnagar (Gujarat State, India). International Journal of Advance Research and Innovative Ideas in Education, 3, 211-224.

Nicholls, J., Li, F., Roslow, S., \& Kranendonk, C. J. (2002). The Seven Year Itch? Mall Shopper across Time. Journal of Consumer Marketing, 19, 149-165. https://doi.org/10.1108/07363760210420568

Oakley, A. (1975). The Sociology of Housework. New York: Pantheon Books.

Ooi, J. T. L., \& Sim, L. L. (2007). The Magnetism of Suburban Shopping Centers: Do Size and Cineplex Matter. Journal of Property Investment and Finance, 25, 111-135. https://doi.org/10.1108/14635780710733816

Oppewal, H. (1995). Conjoint Experiments and Retail Planning: Modelling Consumer Choice of Shopping Centre and Retail Reactive Behaviour. PhD Thesis, Eindhoven: University of Technology. 
South, S. J., \& Spitze, G. (1994). Housework in Marital and Non-Marital Households. American Sociological Review, 59, 327-347. https://doi.org/10.2307/2095937

Stockil, P. (1972). The Mall. In C. Darlow (Ed.), Enclosed Shopping Centres (pp. 52-62). London: Architectural Press.

Stoel, L., Wickliffe, V., \& Lee, K. H. (2004). Attributes Beliefs and Spending as Antecedents to Shopping Value. Journal of Business Research, 57, 1067-1073. https://doi.org/10.1016/S0148-2963(03)00016-X

Tauber, E. M. (1972). Why Do People Shop? Journal of Marketing, 36, 46-49. https://doi.org/10.1177/002224297203600409

Terblanche, N. S. (1999). The Perceived Benefits Derived from Visits to a Super Regional Shopping Centre: An Exploratory Study. South Africa Journal of Business Management, 30, 141-146. https://doi.org/10.1080/08961530903476113

Timmermans, H. (1996). A Stated Choice Model of Sequential Mode and Destination Choice Behaviour for Shopping Trips. Environment and Planning A: Economic and Space, 28, 173-184. https://doi.org/10.1068/a280173

Timmermans, H., \& Waerden, P. V. (1992). Modelling Sequential Choice Processes: The Case of Two-Stop Trip Chaining. Environment and Planning A: Economic and Space, 24, 1483-1490. https://doi.org/10.1068/a241483

Timmermans, H., Borgers, A., \& Waerden, P. V. (1992). Choice Experiments versus Revealed Choice Models: A Before-After Study of Consumer Spatial Shopping Behaviour. The Professional Geographer, 44, 406-416. https://doi.org/10.1111/j.0033-0124.1992.00406.x

Timmermans, H. J. P., Vander, H. R., \& Westerveld, H. (1984). Decision-Making between Multi Attribute Choice Alternatives: A Model of Spatial Shopping Behaviour Using Conjoint Measurements. Environment and Planning A: Economic and Space, 16, 377-387. https://doi.org/10.1080/04353684.1984.11879499

Underhill, P. (2009). Why We Buy. New York: Simon and Schuster.

Venkateswarulu, A., \& Uniyal, D. P. (2007). Concept of a Mall: Measuring Attitude and Perception of Shoppers towards Malls of Mumbai. Indian Retail Review, 1, 7-16.

Wakefield, K., \& Baker, J. (1998). Excitement at the Mall: Determinants and Effects on Shopping Response. Journal of Retailing, 74, 515-539. https://doi.org/10.1016/S0022-4359(99)80106-7

White, R., \& Sutton, A. (2001). Social Planning for Mall Redevelopment: An Australian Case-Study. Local Environment, 6, 65-80. https://doi.org/10.1080/13549830120024251

Wilhelm, W. B., \& Mottner, S. (2005). Teens and Shopping Mall Preferences: A Conjoint Analysis Approach to Understanding the Generational Shift toward an Experiential Economy. Journal of Shopping Centre Research, 12, 23-52. 